\title{
Queenship and Power
}

\author{
Series Editors
}

Charles Beem

University of North Carolina, Pembroke

Pembroke, NC, USA

Carole Levin

University of Nebraska-Lincoln

Lincoln, NE, USA 
This series focuses on works specializing in gender analysis, women's studies, literary interpretation, and cultural, political, constitutional, and diplomatic history. It aims to broaden our understanding of the strategies that queens-both consorts and regnants, as well as female regents-pursued in order to wield political power within the structures of male-dominant societies. The works describe queenship in Europe as well as many other parts of the world, including East Asia, Sub-Saharan Africa, and Islamic civilization.

More information about this series at

http://www.springer.com/series/14523 
Sarah Duncan - Valerie Schutte

Editors

The Birth of a Queen

Essays on the Quincentenary of Mary I 


\section{Editors}

Sarah Duncan

Spring Hill College

Mobile, AL USA
Valerie Schutte

Independent Scholar

Pittsburgh, PA USA

Queenship and Power

ISBN 978-1-137-59748-9

ISBN 978-1-137-58728-2 (eBook)

DOI $10.1057 / 978-1-137-58728-2$

Library of Congress Control Number: 2016948585

(C) The Editor(s) (if applicable) and The Author(s) 2016

This work is subject to copyright. All rights are solely and exclusively licensed by the Publisher, whether the whole or part of the material is concerned, specifically the rights of translation, reprinting, reuse of illustrations, recitation, broadcasting, reproduction on microfilms or in any other physical way, and transmission or information storage and retrieval, electronic adaptation, computer software, or by similar or dissimilar methodology now known or hereafter developed.

The use of general descriptive names, registered names, trademarks, service marks, etc. in this publication does not imply, even in the absence of a specific statement, that such names are exempt from the relevant protective laws and regulations and therefore free for general use. The publisher, the authors and the editors are safe to assume that the advice and information in this book are believed to be true and accurate at the date of publication. Neither the publisher nor the authors or the editors give a warranty, express or implied, with respect to the material contained herein or for any errors or omissions that may have been made.

Cover illustration: (C) Mary I blessing cramp rings (pigment on vellum), English School, (16th century) / Westminster Cathedral Library, UK / Bridgeman Images

Printed on acid-free paper

This Palgrave Macmillan imprint is published by Springer Nature

The registered company is Nature America Inc. New York 


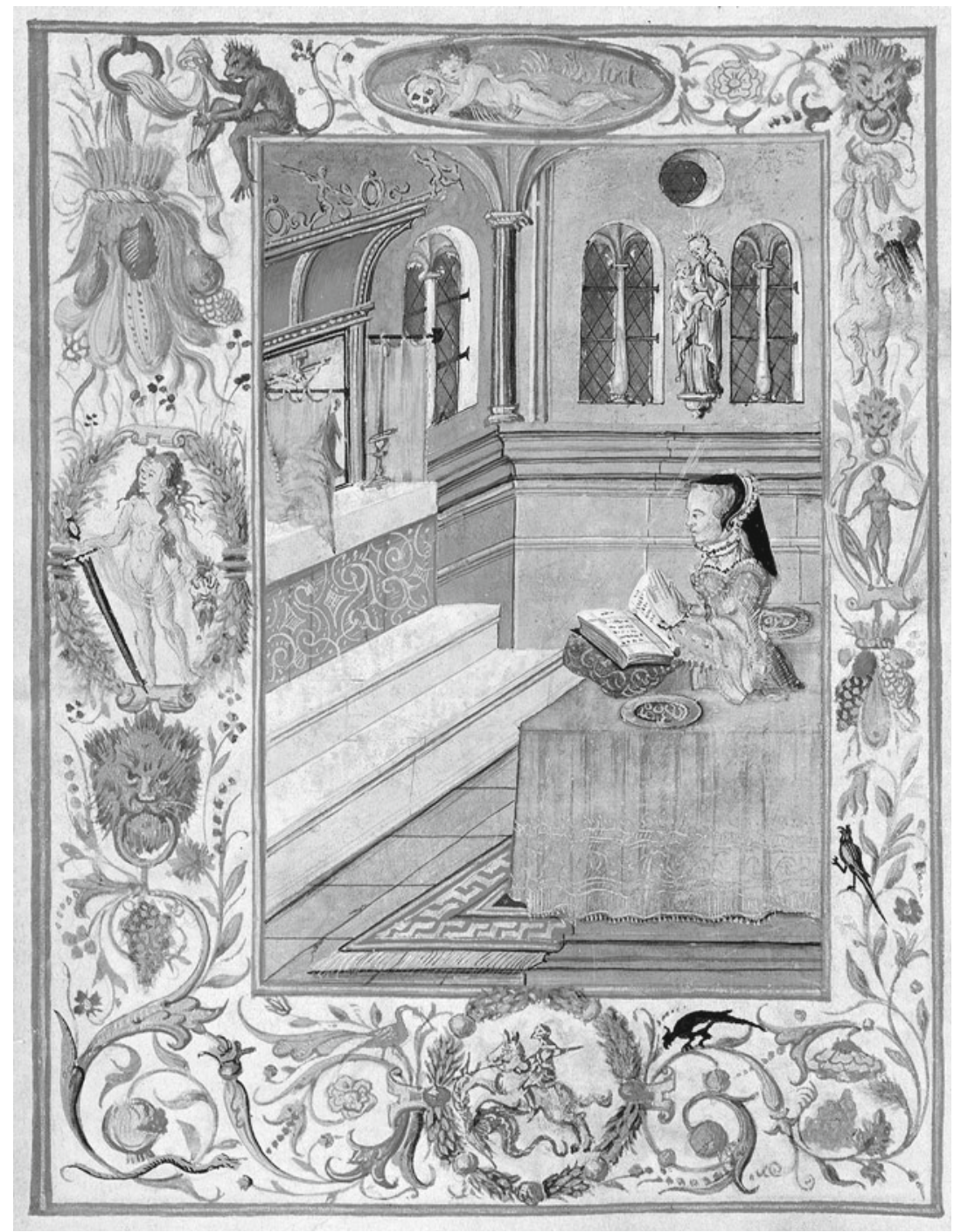





\section{Key Events in the Life of Mary I}

February 18, 1516

May 1525

February 1531-1534

January 25, 1533

September 7, 1533

March 1534

January 7, 1536

May 19,1536

June 22, 1536

October 12,1537

July 1543

January 28, 1547

July 6,1553

July 10,1553

July 19, 1553

August 3, 1553

September 29-October 1, 1553

January 25-February 7, 1554

July 25,1554

November 28, 1554

November 30, 1554

February 1, 1555

August 29, 1555

March 19, 1557

June 7, 1557

July 6, 1557

November 17, 1558
Mary born at Greenwich Palace

Mary moves to Ludlow Castle, Wales for 19 months

Henry VIII breaks from Catholic Church

Henry VIII marries Anne Boleyn

Elizabeth born

Act of Succession declares Mary illegitimate

Catherine of Aragon dies

Anne Boleyn executed

Mary accepts Act of Succession

Edward born

Act of Succession puts Mary in line for throne

Henry VIII dies

Edward VI dies

Lady Jane Grey proclaimed queen

Mary proclaimed queen in London

Mary makes royal entry into London

Mary's coronation

Wyatt's Rebellion

Marriage of Mary and Philip of Spain at Winchester

Cathedral

Announcement of Mary's pregnancy

Reconciliation with Rome

Beginning of Protestant heretic burnings

Philip leaves England

Philip returns to England

England declares war on France

Philip leaves England for the last time

Mary dies 



\section{ACKNOWLEDgments}

We owe a great deal of thanks to the individuals who have made this publication possible. First and foremost to Carole Levin and Charles Beem, who showed interest in a collection celebrating Mary's birthday for their Queenship and Power series. Not only are they our series editors, but each has contributed wonderful essays to the collection and also recruited others to submit essays as well. We are also very grateful for the assistance given by our editorial team at Palgrave, USA, particularly Kristin Purdy and Michelle Smith. This volume would not be as meaningful without all of its contributors, and we thank them for their hard work.

Valerie would like to thank Sarah for taking on this endeavor with her and "herding cats" for the last year. She would also like to thank her family for their support, attendance at numerous conferences, and needed distractions.

Sarah would like to thank Valerie both for originating the idea of a book to commemorate the anniversary of Mary I's birthday and for inviting her to take part in it. She would also like to thank Steven, Duncan, and Parker for their support, understanding, and willingness to go out of town without her during crucial deadlines (even those weekend trips to New Orleans). 



\section{Contents}

1 Introduction: Princess, Bastard, Queen, Villain I Sarah Duncan and Valerie Schutte

Part I From Princess to Queen

2 Princess of Wales? Mary Tudor and the History of English Heirs to the Throne

Charles Beem

3 Under the Influence: The Impact of Queenly Book Dedications on Princess Mary

Valerie Schutte

4 Lady Mary to Queen of England: Transformation, Ritual, and the Wardrobe of the Robes Hilary Doda 
5 The Half-Blood Princes: Mary I, Elizabeth I, and Their Strategies of Legitimation

Mary Hill Cole

6 "A queen, and by the same title, a king also": Mary I:

Queen-in-Parliament Anna Whitelock

7 The Queen's Easter Pardons, 1554: Ancient Customs and the Gift of Thucydides

G. Gibbs

8 Sovereign Council or Counseled Sovereign: The Marian Conciliar Compromise Joanne Paul

9 Culture Under Mary I and Philip Alexander Samson

10 Pregnancy, False Pregnancy, and Questionable Heirs: Mary I and Her Echoes

Carole Levin

11 Unnatural, Unlawful, Ungodly, and Monstrous: Manipulating the Queenly Identities of Mary I and Mary II 
12 "Well, then ... Hail Mary": Mary I in The Famous

History of Sir Thomas Wyatt (1607) and Lady Jane (1986) 215

Carolyn Colbert

13 Marrying Mary to the Black Legend: Anti-Catholicism and Anti-Marian Messages in Anglo-American Films about Philip II of Spain

William B. Robison

14 Mary I, Queen of England: Historiographical Essay, 2006 to Present

Retha Warnicke

Contributors

Index 



\section{LisT OF TABLES}

Table 4.1 Color of garments and textiles purchased by and for Henry VIII and Mary I from 1531 to 1547

Table 4.2 Coronation robes of the Tudor Monarchs (to 1553) 